\title{
Automatic Height and Weight Measurement Integrated Database System
}

Uci Rahmalisa ${ }^{1}$, Yulisman ${ }^{2}$

${ }^{1,2}$ Sistem Informasi, STMIK Hang Tuah Pekanbaru

\begin{tabular}{l} 
Article Info \\
\hline Article history: \\
Received 11 14, \\
Revised 1210,202 \\
Accepted 12 14, \\
\hline Keywords: \\
Automatic scale \\
Arduino Uno \\
C Language \\
Visual Basic \\
Database
\end{tabular}

Corresponding Author:

Uci Rahmalisa

Sistem Informasi

STMIK Hang Tuah Pekanbaru

Jl.Mustafa Sari No.5 Tangkerang Selatan

Email: ucirahmalisa89@gmail.com

(C) The Author(s) 2021

\begin{abstract}
Measurement of height and weight, it is needed especially for school age 5-15 years old. From the results of monitoring height and weight measurements, we can monitor whether the child is underweight or overweight and obese. We can also monitor the growth of elementary school age children. The problem faced is that monitoring the growth of children in schools cannot be carried out effectively. This is because the process of measuring children's height and weight is done manually and of course it takes time for the process, besides that, data on student height and weight are also recorded still manually, so that data processing and utilization is not optimal. The purpose of making this Automatic Height and Weight Measurement Integrated Database System to process of measuring height and weight can be done effectively and efficiently, so it can produce integrated information in Database. The existence of an integrated database will make it easier for related parties to recap and archive children's data and store history of children's growth as material for evaluating and monitoring child growth. The results of this evaluation can be used as a reference for follow-up to be conducted. The resulting output is information in the form of tables and graphs of children's growth. In this research using the prototyping method which aims to get an overview of the tool to be designed and built, then it will be evaluated by the user. The evaluated prototype will be used as a reference to make a tool as the final product as the output of this research.
\end{abstract}

This is an open access article under the CC BY-SA license.

\section{Introduction}

Physical growth in students leads to increasing the height of students, its peak after the age of 0-3 years old is at school age of 6-12 years [1]. Elementary school students are nutritionally vulnerable group who are easily affected by nutritional disorders, which is condition that causes nutritional status to be in unbalanced condition. The results of the Basic Health Research [2], showed national prevalence of underweight school children (aged 6-14 years). One of the indicators to assess the nutritional status of school-age is monitoring the height and weight of new students just entered school. The height of new students just entered school can provide an overview of the previous age growth which is closely related to past health and nutrition history, while weight is related to the condition of his nutritional status in the present [2].

The system for measuring student height and weight is still manually so it takes much to process. The measurement process begins with weighing and continuing with measuring height, through two different steps, after that, the data will record manually into the book, then make the report as monitoring of the results of 
student weight and height. Based on the description above, students' height and weight measurement activities can be carried out simultaneously by designing an Automatic Height and Weight Measurement tool equipped with an Integrated Database System. This tool is presented to provide convenience for related parties in the process of measuring student weight and height. It can be carried out simultaneously and with an integrated database all measurement data can be stored automatically to generate reports on the results of measuring student weight and height growth. This automatic measurement result report can be used as evaluation material for related parties to make a policy in realizing healthy young generation. Follow-up can be given by giving milk, nutritious food, sports activity facilities, etc.

\section{Research Method}

This research was conducted by building a prototype first and then implementing it to related parties. The prototype model can be used to connect customer misunderstandings about technical matters and clarify the specifications of the customer's desired needs to application makers [11]. The steps of the Prototype model are:

1. The researcher will collect the data needed in the process of making the tool, it is the first step to find a problem formulation related to how to design an automatic student height and weight measuring device/tool integrated into database system by providing output in the form of height and weight growth chart body of each student.

2. Then a prototype program will be made to provide an overview to the customer. The prototypes will be provided are as follows:

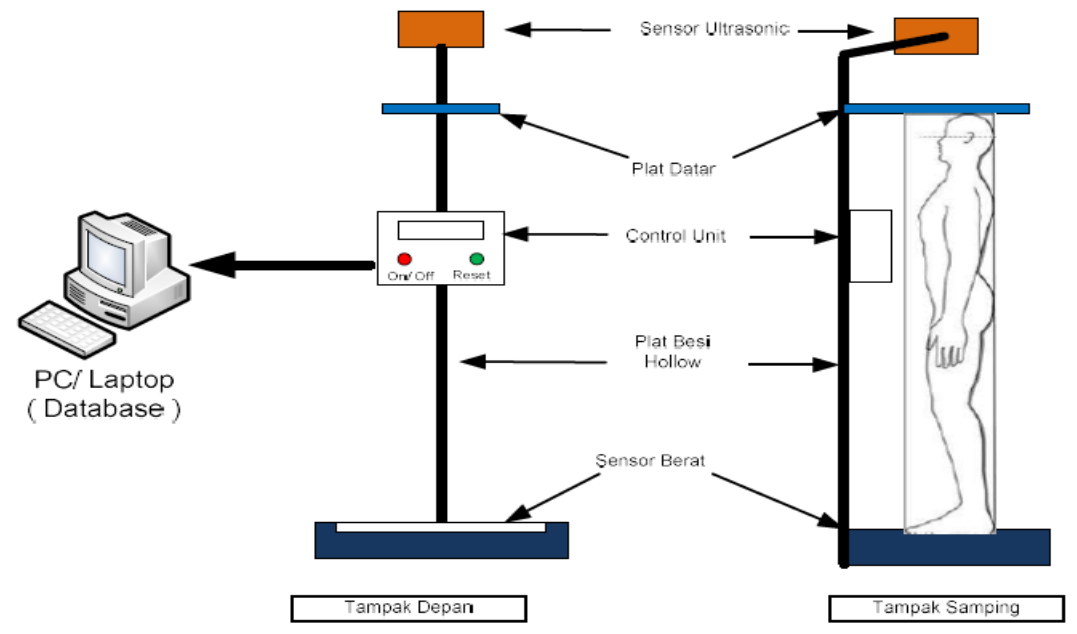

Figure 1 Automatic Height and Weight Measurements Design

The following is the layout of Control Unit design of automatic height and weight measuring machine design will be made.

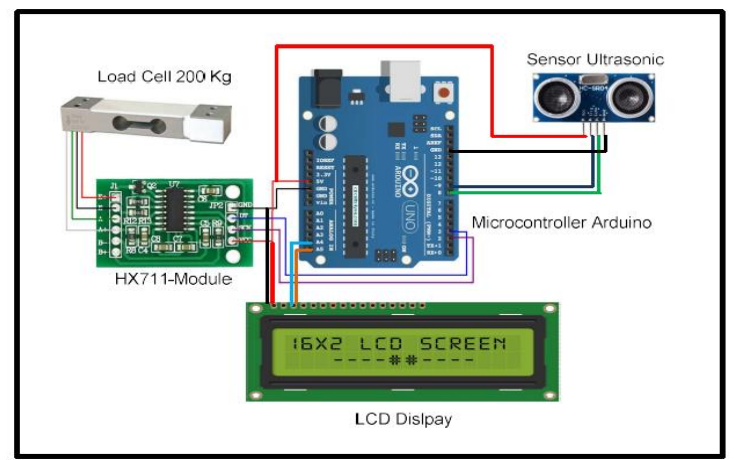

Figure 2 Layout Control Unit Design of Automatic Height and Weight Measuring Machine Information :

1. The load cell functions as a weight sensor to measure the object's weight 
2. The measurement results from the load cell will be converted into digital data via the HX711 module to obtain the object's weight in $\mathrm{Kg}$.

3. The ultrasonic sensor functions to measure the distance of object, in this case it is to measure the distance from the top of the measuring machine to flat plate that is placed parallel to object's head. Through a simple mathematical equation, the ultrasonic measurement results can measure the height of object.

4. The results of measuring the weight and height of object will be displayed on LCD screen through data processing carried out on the Arduino Microcontroller

5. The object's height and weight information can also be displayed on the system if the device/tool is connected to a PC/Laptop via USB cable. And the data can be stored into an integrated database to generate reports on the growth of weight and height of objects.

6. The next step is to do demonstration of the device/tool and test it to ensure it runs according to its function properly.

\section{Result and Discussion}

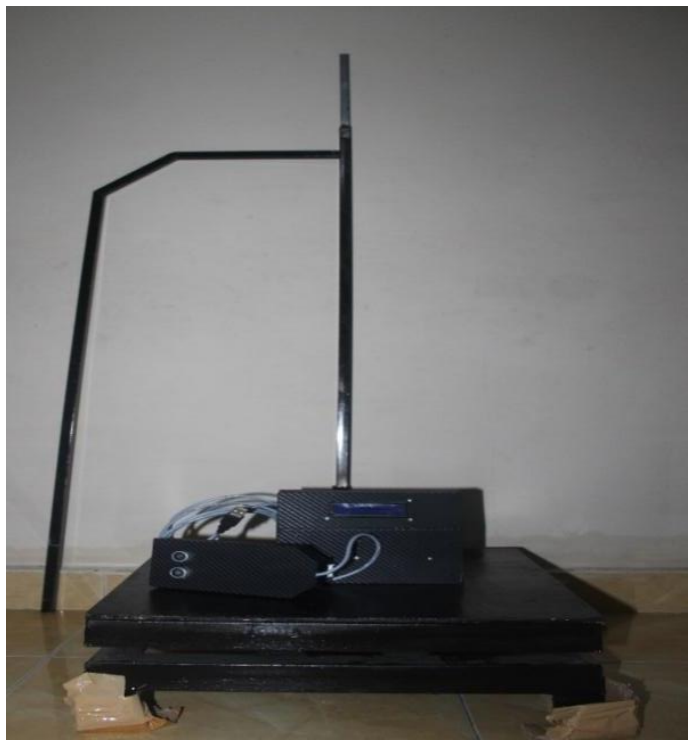

Figure 3 Components of measuring height and weight

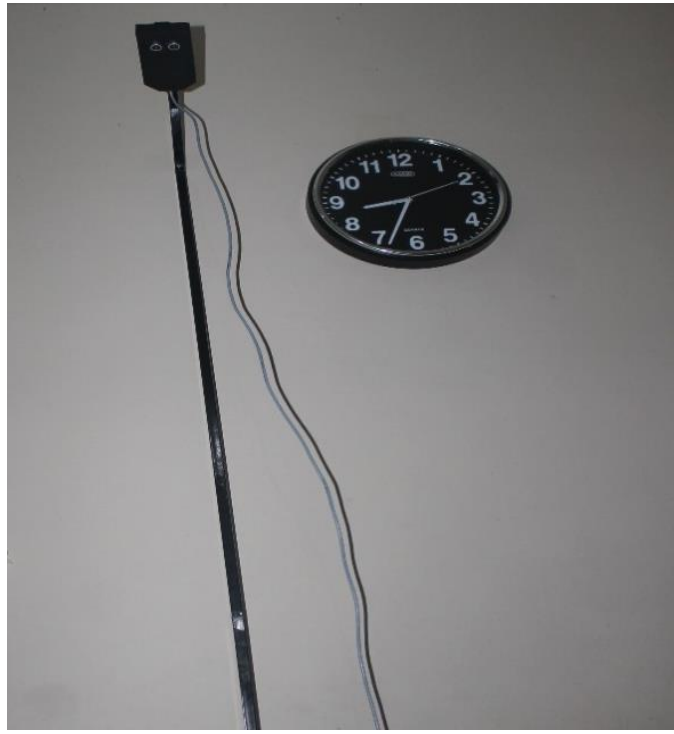

Figure 4 Pole of Height measuring equipped with ultrasonic sensor

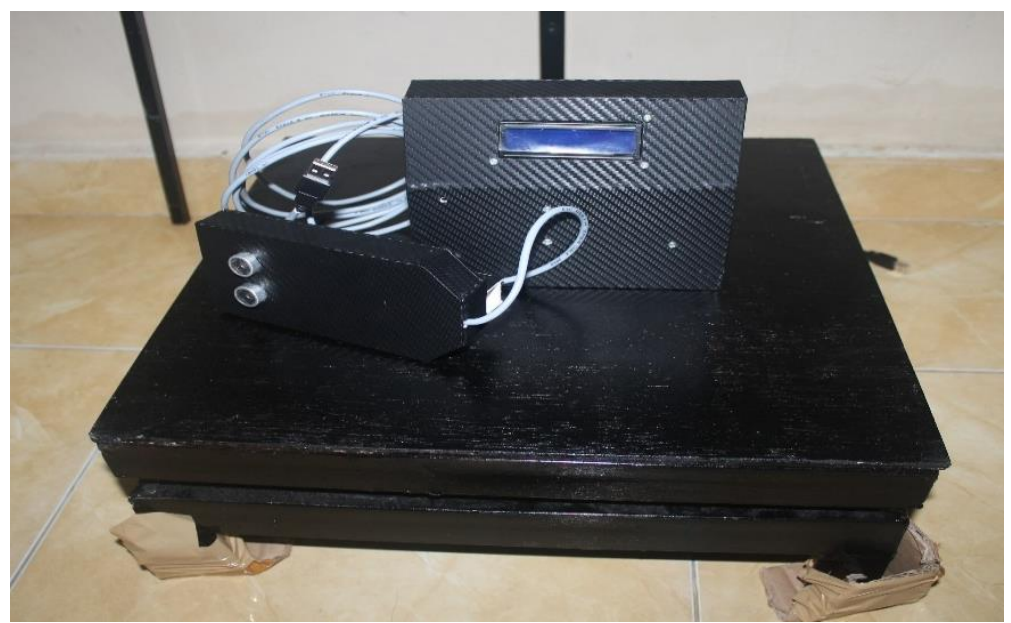

Figure 5 LCD, Ultrasonic Sensor and Weight Scale

Information :

1. The prototype scale is made using an angled iron frame with $0.6 \mathrm{~mm}$ thickness, with $50 \mathrm{~cm}$ length and 50 $\mathrm{cm}$ width.

2. The weight scale is made of multiplex with $9 \mathrm{~mm}$ thickness. 
3. The stand height of the ultra sonic sensor is $190 \mathrm{~cm}$.

4. The connecting cable between microcontroller board and ultrasonic sensor uses telephone cable with 2 meters length.

5. Meanwhile, to measure the weight of the load using a loadcell sensor with a maximum measurement capacity of $200 \mathrm{Kg}$.

6. To display the results of weight and height measurements using $16 \times 2$ LCD.

\section{Test result}

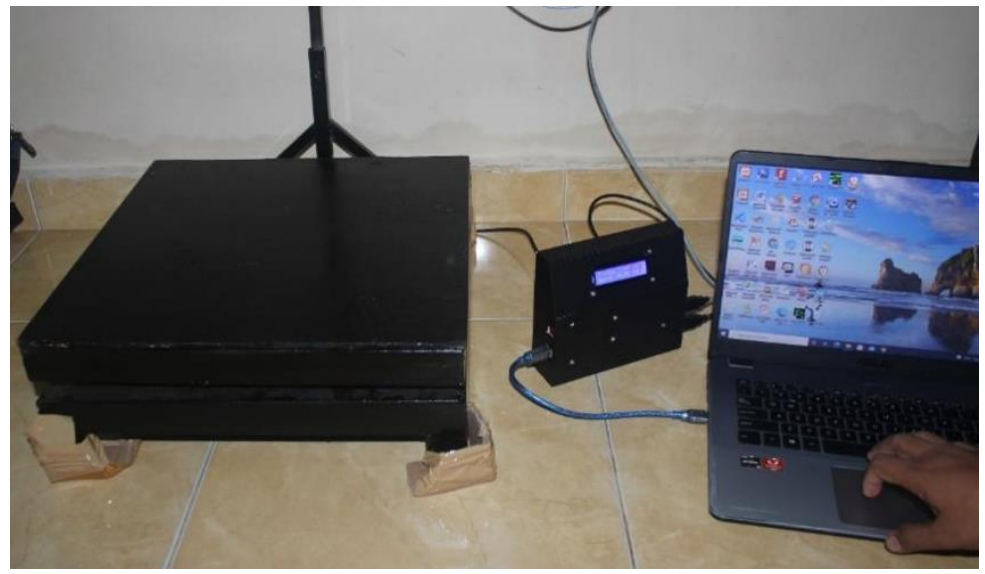

Figure 6 The Process of Testing Height and Weight Measuring Instruments

Tool testing steps:

1. Connect USB cable from the PC/Laptop into Microcontroller Board.

2. Enable MySQL

\begin{tabular}{|c|c|c|c|c|c|c|c|c|}
\hline \multicolumn{8}{|c|}{ XaMpp Control Panel v3.2.4 [Compiled: Jun 5th 2019] } & \multirow{3}{*}{$\begin{array}{l}\square \times \\
\text { (6) Netstat }\end{array}$} \\
\hline भु & \multicolumn{4}{|c|}{ XAMPP Control Panel v3.2.4 } & & & & \\
\hline \multirow[t]{6}{*}{$\begin{array}{l}\text { Modules } \\
\text { Service }\end{array}$} & Module & PID(s) & Port(s) & Actions & & & & \\
\hline & Apache & & & Start & Admin & Config & Logs & 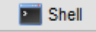 \\
\hline & MySQL & 5496 & 3306 & Stop & Admin & Config & Logs & Explorer \\
\hline & FileZilla & & & Start & Admin & Config & Logs & Services \\
\hline & Mercury & & & Start & Admin & Config & Logs & (9) Help \\
\hline & Tomcat & & & Start & Admin & Config & Logs & Quit \\
\hline
\end{tabular}

Figure 7 XAMPP Application

3. Log in the weighing application

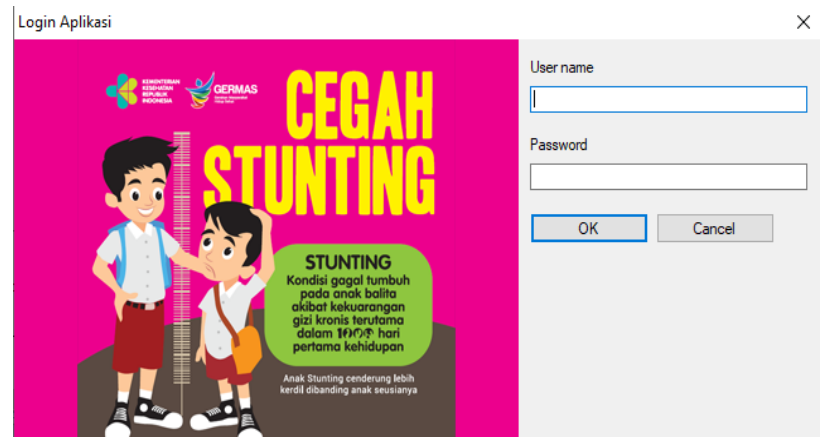

Figure 8 Login Form

4. Input Student/child data to be weighed on the Student Data Input form

Jurnal Teknologi dan Open Source, Vol. 4, No. 2, December 2021: 248 - 253 


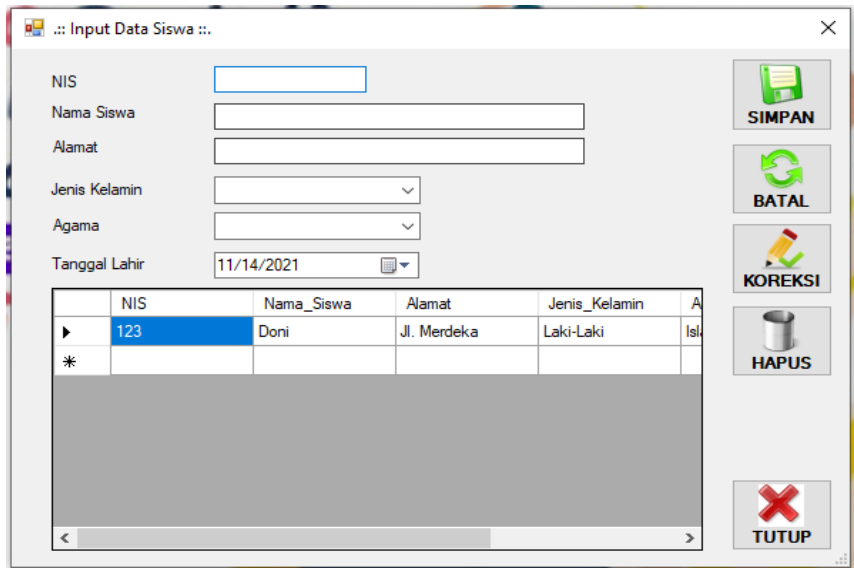

Figure 9 Student Data Input Form

5. Activate the form of student's height and weight measurement

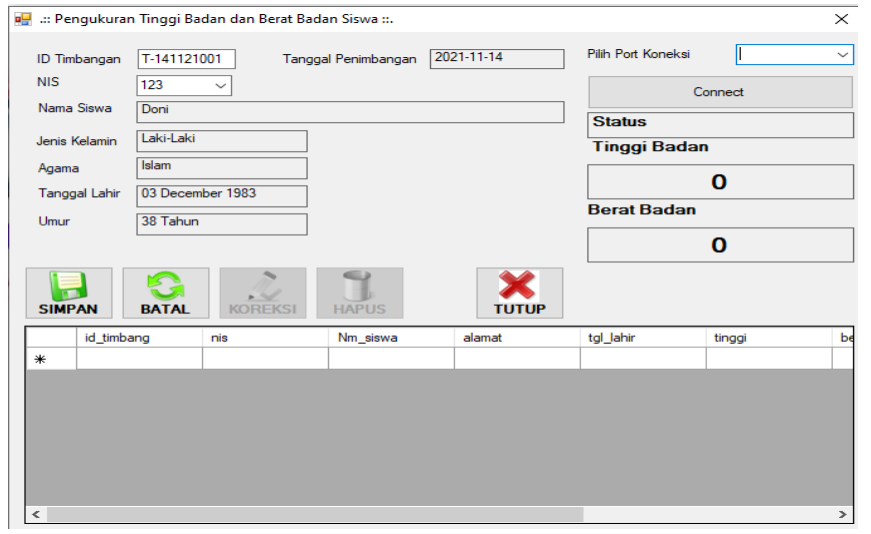

Figure 10 Form of Student's height and weight measurement

6. Select the connection port to the weighing device then click the Connect button, then the results of weight and height measurements will be displayed on the form. Click "SAVE" button to save the weighing data.

7. To display weighing data, click the Report menu and click "Print Student Data" button to print all student data, and select student NIS to print student weighing data

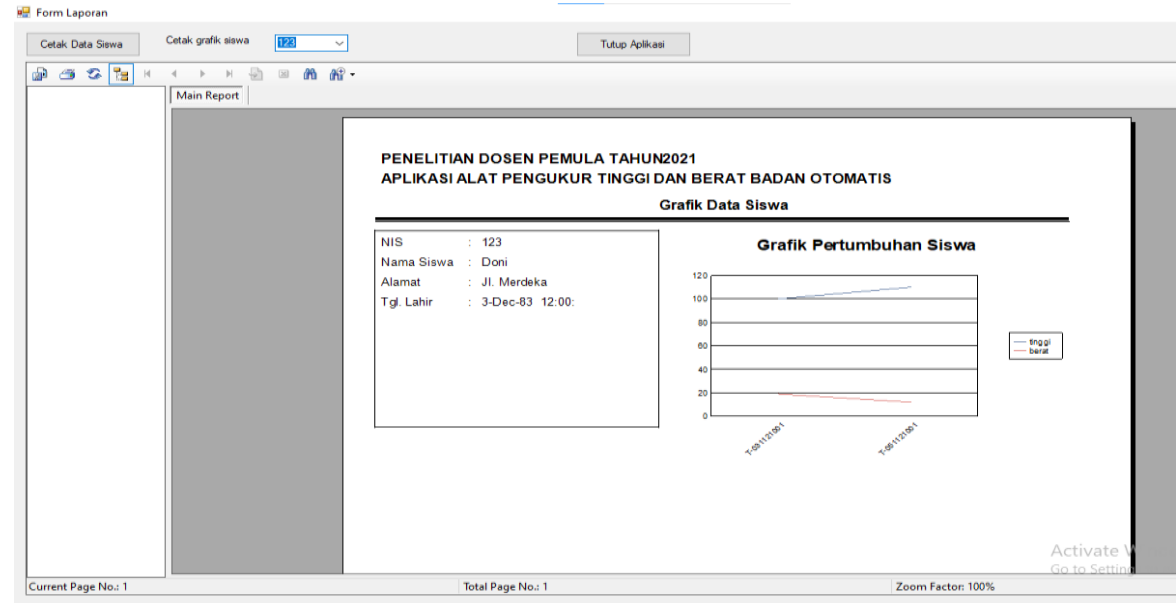

Figure 11 The report of Student Data Graph

\section{Conclusion and Suggestion}

\section{Conclusion :}


In this research with the title Automatic height and weight integrated database system was conducted the testing and it has been obtained the following conclusions:

1. The accuracy of digital scales and height measurement is up to $98 \%$.

2. The weighing device can be connected to a desktop application using Visual Basic .Net programming with MySQL database.

3. The application can display the data on the results of scales in the form of graph.

\section{Suggestion :}

This height and weight measuring device/tool uses a develope application based on desktop with local database, so the data cannot be accessed in real time via internet network. For further development, it is hoped that the height and weight measuring device/tool can be connected to Android-based smartphone, so it can provide easy access to users without being dependent on a single device.

\section{Acknowledgement}

We would like to thank the related parties who have given us the opportunity to conduct this research, facilitate our research process to completion until we finally publish the results of our research journal.

\section{References}

[1] Andrianto, H., \& Darmawan, A. (2016). Arduino; Belajar Cepat dan Pemrograman.

[2] D. U. Erna Kusuma Wati, Purnamasari, "Analisis Tinggi Dan Berat Badan Anak Baru Masuk Sekolah Sebagai Deteksi Dini Gangguan Gizi Pada Anak Usia Sekolah Dasar,” J. Exp. Psychol. Gen., vol. 5, no. 1, pp. 23-42, 2017.

[3] D. A. A. Yu, M. A. D. Amayanti, I. K. E. J. Unitha, I. D. A. B. Agus, and M. A. D. E. S. Uaskara, "Pola Pertumbuhan Berdasarkan Berat Dan Tinggi Badan Siswa Pada Sekolah Negeri Dan Swasta Di Kota Denpasar , Bali Growth Pattern Based on Height and Body Weight From Students of Government and Private School At Denpasar , Bali," vol. 21, no. 2, pp. 78-87, 2017.

[4] H. A. Dharmawan, Mikrokontroller: Konsep Dasar dan Praktis. Universitas Brawijaya Press, 2017.

[5] K. W, Panduan Belajar MySQL Database Server. Media Kita, 2010.

[6] Kadir, A. (2017). Pemrograman arduino dan processing. Elex Media Komputindo.

[7] Linarta, A., \& Nurhadi, N. (2018). Sistem Informasi Penjadwalan Bel Sekolah Otomatis Berbasis Microcontroller. JURNAL UNITEK, 11(2), 87-98.

[8] Rahmalisa, U., Mardeni, M., Helmi, R., \& Linarta, A. (2020). Pemberi makan otomatis pada kucing menggunakan raspberry pi berbasis android. Jurnal teknologi dan open source, 3(2), 298-308.

[9] Radillah, T., Widodo, P. P., \& Linarta, A. (2017, November). Aplikasi Optimalisasi Layanan Kunjungan Rutan Klas IIB Dumai Berbasis Sms Auto Response (SAR). In Prosiding Seminar Nasional (Vol. 1, No. 1, pp. 150-164).

[10] Sugiarto, M. I., Linarta, A., \& Sofiyan, A. (2019). Aplikasi Layanan Informasi Absen dan Nilai Berbasis SMS Gayeway Menggunakan PHP pada SMK Taruna Persada Dumai. Informatika, 9(2), 60-69.

[11] S. Sarayati, "Analisis Faktor Perilaku Seksual Pada Anak SD di SDN Dukuh Kupang II - 489 Kecamatan Dukuh Pakis Kelurahan Dukuh Kupang Surabaya,” ADLN Perpust. Univ. Airlangga, pp. 11-76, 2016, [Online].

[12] T. Sutabri, Analisis sistem informasi. Andy.

[13] V. J. Matali, H. I. S. Wungouw, and I. Sapulete, "Pengaruh Asupan Susu terhadap Tinggi Badan dan Berat Badan Anak Sekolah Dasar," J. e-Biomedik, vol. 5, no. 2, 2017, doi: 10.35790/ebm.5.2.2017.18512.

[14] Wasista, S., Saraswati, D. A., \& Susanto, E. (2019). Aplikasi Internet of Things (IOT) dengan Arduino dan Android "Membangun Smart Home Dan Smart Robot Berbasis Arduino Dan Android". Deepublish. 